\title{
Bilkent Üniversitesi Kütüphanesi: Türk Plastik Sanatlar Arşivi
}

\author{
Bilkent University Library: Turkish Plastic Arts Archive
}

\section{Şelale Korkut ${ }^{*}$}

Öz

Bu makalede, Bilkent Üniversitesi Kütüphanesi Plastik Sanatlar Arşivi'nin kuruluşu, gelişimi, verdiği hizmetler ve gerçekleştirmek istediği hedefler ayrıntılı olarak anlatılmaktadır.

Anahtar sözcükler: Bilkent Üniversitesi Kütüphanesi, Türk Plastik Sanatlar Arşivi, Üniversite kütüphaneleri, Kütüphane tanıtımı, Kütüphane hizmetleri.

\begin{abstract}
The present paper describes the Turkish Plastic Arts Archive at the Bilkent Univiersity Library. Its foundation, development, nature of services and aims to be followed were explained in detail.
\end{abstract}

Keywords: Bilkent University Library, Turkish Plastic Arts Archive, University libraries, Library publicity, Library services.

\section{Giriş}

Bilkent Üniversitesi Kütüphanesi Sanat Odası'nda hizmet verilmekte olan Türk Plastik Sanatlar Arşivi resmi olarak 1990 yılında kurulmuş olup, çalışmalar o günden bugüne aralıksız devam etmektedir.

\footnotetext{
*Sanat Odası Birim Amiri; Bilkent Üniversitesi Kütüphanesi 06800 Bilkent-Ankara (artlibrary@bilkent.edu.tr).
} 


\section{Türk Plastik Sanatlar Arşivi}

Türk Plastik Sanatlar Arşivi, çağdaş Türk sanatçıları hakkında güncel bilgilere erişmenin son derece güç olması; sergi davetiyesi ve kataloğu, broşür, bülten, poster gibi belgelerin ise zaman içinde yitip gitmesi sonucu, ulaşılamaz duruma gelmesi nedeniyle çağdaş Türk plastik sanatı ve bu alanda çalışanlara hizmet vermek amacıyla kurulmuştur.

Arşiv; dergi makaleleri, gazete kupürleri, sergi davetiyeleri, sergi katalogları, broşür, bülten, afiş, takvim ve reprodüksiyonlardan oluşmaktadır. Bunun yanı sıra Sanat Odası koleksiyonunda bulunan yaklaşık 26.000 sanat kitabı bulunmaktadır. Koleksiyonun oldukça önemli bir bölümünü Türk plastik sanatları konusundaki kitaplar oluşturmaktadır. Koleksiyonun gelişmesi için sürekli olarak piyasaya yeni çıkan kitaplar izlenmekte, bağış veya satın alma yoluyla yeni yayınlar koleksiyona eklenmeye çalışılmaktadır.

Arşiv koleksiyonuna girecek materyaller şunlardır:

- Resim, heykel, seramik, baskı, video sanat, grafik, enstalasyon ve bunlarla ilişkili olan performans sanatıyla ilgili belgeler,

- Yine aynı konularla ilişkili olan sanatçıların fotoğraf, karikatür, takı ile ilgili çalışmaları,

- Yarışma duyuruları ve sonuçları,

- Kültür merkezleri ve sanat galerilerinin açılış haberleri,

- Devletin ve yerel yönetimlerin sanat politikaları,

- Modern sanat eserlerini kapsayan müzayede haberleri,

- Türk sanatıyla ilgili kitap ve dergilerin tanıtım yazıları,

- Türk sanatçılarının yurt dışındaki etkinliklerine ilişkin haberleri,

- Sanat ödülü alan sanaçların veya onların eserlerinin haberleri,

- Sanatçıların ölüm haberleri,

- Anıt-heykeller ile ilgili haberler,

- Müze, okul, dernek, sanat kütüphanesi gibi sanat kurumları ile ilgili haberler,

- Sanatla ilgili bienal, konferans, sempozyum haberleri, 
- Sanatçı biyografileri,

- Genel sanat akımları hakkında bilgi veren yazılar,

- Geleneksel fresk türü uygulamalar hariç duvar resmi ile ilgili yazılar,

- Türkiye'deki özel sanat koleksiyonları ve sergileri,

- Modernize edilmiş olarak ele alınan çini, halı, kilim, dokuma ve işleme ile ilgili yazılar ve belgeler,

- Resmin bir ögesi olarak kullanılan ebru ve kaligrafi ile ilgili yazılar ve belgeler, 19. yüzyıl ve sonrası çalışmalar sayılabilir.

Arşiv için, Eylül 2004 tarihine kadar yayımı devam eden veya durmuş 73 dergi ve 12 gazete taranmış olup, bu sayı sürekli artmaktadır. Sanat konulu dergilerin yanı sıra zaman zaman sanat haberlerine de yer veren dergiler taranmaktadır. Taranan dergilerin listesi Arşiv'in web sayfasında listelenmektedir. Taranan gazete ve dergiler kartekse işlenmekte, geç gelen ve yayımı duran dergilerin izlenmesi karteksden yapılmaktadır.

Gazeteler 1988 yılından itibaren taranmış olmakla beraber, dergilerde tarih 1935'lere kadar inmektedir. Taranan dergilerde arşive alınan makalelerin başlığının yanına ufak bir işaret konulmaktadır. Böylece dergiye bakıldığında hangi makalenin arşivde kataloglandığı anlaşılmaktadır.

Sanat Odası'nda çalışmakta olan biri sanat tarihçi olmak üzere, üç kütüphaneci ve diğer üniversite mezunlarından oluşan toplam yedi kişi arşivle ilgili çeşitli işleri paylaşarak okuyuculara hizmet vermektedirler. Kataloglama yapan kişilerde konuya hakimiyet yani konu uzmanlığı aranmaktadır.

BLISS Kütüphane Otomasyon Sistemi içinde "Bilkent Üniversitesi Kütüphanesi Türk Plastik Sanatlar Arşivi" veri tabanı altında MARC formatında kataloglama yapılmakta ve Library of Congress Subject Headings (LCSH) konu başıkları listesinden Ingilizce konu başıkları kullanılmaktadır. Kullanılan konu başlıklarını içeren bir liste tutulmaktadır. Belgelere olabildiğince özel konu başlıkları verilmekte; gerekli olduğunda verilecek konu başı̆ğı ile ilgili araşııma yapılarak yeni başlıklar bu listeye eklenmektedir. Kataloglanan belgeler hatayı en aza indirgemek için, ikinci bir kişi tarafından son bir kez kontrol edildikten sonra dosyalarına yerleştirilmektedir. 
Arşiv istatistiksel bilgiler açısından değerlendirildiğinde; Eylül 2004 sonu itibariyle; 6.495 davetiye, 446 afiş, 74 bülten, 19.847 makale, 152 broşür, 37 takvim, 12.598 kupür, 513 reprodüksiyon, 1.169 sergi kataloğu olmak üzere toplam 41.326 belgenin kataloglandığı görülmektedir. Bu birimde ayda ortalama 250-300 katalog girişi yapılmaktadır.

Arşiv çalışanları ayrıca; Türkiye'deki sanat galerilerinin bir listesini tutmakta ve bunu sürekli güncellemektedir. Ancak galeriler çok sık kapanıp, yenilerinin açılması ya da kısa sürede yer değiştimeleri, gazete ve dergilerin düzenli takip edilmelerini ve galerilerle sürekli irtibat halinde olunmasını gerekli kılmaktadır. Galeri sahiplerinin çoğunu bir arada görmek açısından İstanbul ve Ankara'da açılan sanat fuarlarına katılmak son derece önemlidir. Fuarlarda sanatçı ve galeri sahipleri ile tanışılarak arşiv için belge göndermeleri istenmektedir. Ayrıca, zaman zaman galerilerle telefon görüşmesi de yapılmaktadır.

Gelen davetiyelerin de istatistiği tutulmaktadır. Bir galeri ile görüşüldüğünde bu istatistik sayesinde en son hangi yıl ve hangi ayda davetiye gönderdiği söylenebilmektedir. Bu da eksiklerin tespiti açısından son derece yararlı olmaktadır. Yeni gelen davetiyeler istatistiğe işlenip, Ankara'daki bir etkinlik ise, önce Sanat Odası'ndaki panoya asılarak kullanıcılara duyurulmakta, zamanı geçenler ise kataloglanmaktadır.

Her sanatçıya bir dosya açılmakta ve her dosya açılan sanatçının adı “Dosyası Olan Sanatçılar Listesi”ne eklenmektedir. Eylül 2004 sonu itibariyle toplam açılmış sanatçı dosya sayısı 3.158'dir. Dosyaya girebilecek boyutta olan belgeler yani davetiye, kupür, broşür, bülten ve küçük boyutlu reprodüksiyonlar bu dosyalarda tasniflenmektedir. Genel sanat haberleri veya birkaç sanatçıdan bahseden kupürler ise, gazete adına açılan dosyalarda tutulmaktadır. Kupürler kesilip beyaz kağıda yapıştırılmakta ve bütün belgeler damgalanıp sonra yerlerine yerleştirilmektedir. Dosyalar çelik dolaplarda saklanmaktadır.

Sağlama Birimi tarafından barkod verilmiş olan sergi kataloğu, takvim, poster ve reprodüksiyonlar hariç diğer belgelere erişim ve sınıflandırma numarası Sanat Odası tarafından verilmektedir. Tasnif numarası sanatçının soyadının ilk üç harfi ve adının baş harfinden oluşan bir kod ve numaradan 
oluşmaktadır. Erişim numarası ise arşivdeki her bir belgeye verilen bir çeşit barkod numarasıdır. Sınıflandırma numarasının izlenmesi yer dizini kartlarından, erişim numarasının ise katalog yapan kişiler tarafından yapılmaktadır. Sağlama Birimi tarafından barkod verilmiş materyallere hem "Bilkent Üniversitesi Kütüphanesi"den, hem de "Bilkent Üniversitesi Kütüphanesi Türk Plastik Sanatlar Arşivi” veri tabanlarından ulaşılabilmektedir.

Poster, takvim ve barkod almış reprodüksiyonlar özel çekmeceli dolaplarda muhafaza edilmekte; sergi katalogları ise Sanat Ofisinde tutulmaktadır.

Arşivin kullanımı herkese açıktır. Arşivle ilgili isteklere hafta içi 9:00-17:00 saatleri içinde cevap verilmektedir. Ancak makale veri tabanından tarama Sanat Odası'nın açık olduğu herhangi bir saatte yapılabilmektedir.

Bilgisayardan Arşiv veri tabanına girilerek anahtar kelime, sanatçı adı, yazar adı, kurum-galeri adı, konferans-toplantı adı, konu başlıkları gibi birçok kriterden tarama yapılmaktadır.

Arşivi kullanmak isteyen kişi Bilkent Üniversitesi Kütüphanesi'ne gelmiş ise, terminallerden Arşiv veri tabanını seçmekte ve taramasını yapmaktadır. Makale arıyorsa; makalenin künyesini not edip kendisi raftan bularak isterse fotokopisini çektirebilmektedir. Diğerleri için yine sınıflandırma numarasını not etmekte ve Sanat Odası'ndan alacağı form üzerine doldurmaktadır. Orijinal belgeler kullanıcıların eline verilmemekte, istenilen belgelerin fotokopileri çekilerek, fotokopi ücreti karşılığı kullanıcıya verilmektedir. Kullanıcı Ankara dışında ise kendi üniversite kütüphanesi aracılığı ile Bilkent Kütüphanelerarası Ödünç Verme Birimi'nden istem yapabilmektedir.

Internetten Sanat Odasının ve Türk Plastik Sanatlar Arşivinin web sayfalarına ulaşmak mümkündür (http://www.kutuphane.bilkent.edu.tr/ artlibrary TR.htm).

Sanat Odası sayfasında; duyurular, saatler, personel ve iletişim, ödünç verme kuralları, sanat galerisi kullanım kuralları ve web'de bulunan sanat veri tabanları ile ilgili bağlantılar mevcuttur. Arşive tıklandığında ise genel bir bilgi verilmektedir. Sayfadaki diğer başlıklar katalog taraması, taranan gazete ve dergilerin listesi, Arşiv'in kapsamı, galeri listesi ve Arşiv'in nasıl kullanılacağıdır.

Kullanıcı profiline bakıldığında en çok Ankara üniversitelerinde eğitim 
gören sanat öğrencilerine hizmet verildiği görülmektedir. Son iki yılın kullanım istatistiğine göre; 2003'te en fazla kullanım Şubat ayında, 2004'te ise en fazla Mayıs ayında olmuştur.

Arşivin kullanımını artırmak için tanıtım çalışmaları devam etmektedir. Bu çerçevede önceki yıllarda Radikal gazetesinde, Sanat Çevresi ve Şeker Sanat adlı dergilerde tanıtım yazıları yayınlanmıştır. Ayrıca Ekim 2004'te Türk Plastik Sanatlar Arşivi'ni tanııcı bir broşür de hazırlanarak Türkiye'de sanat eğitimi veren üniversitelerdeki ilgili 94 bölüme posta ile gönderilmiştir. Sanat fuarlarına katılmak da tanııı açısından çok önemli kazanımlar sağlamaktadır.

Sanat Odası'nda ayrıca yabancı sanatçı arşivi vardır. Plastik sanatlarla uğraşan çağdaş yabancı sanatçılarla ilgili gazete kupürü ve davetiyeler henüz kataloglanmamakta ancak her sanatçı için ayrı ayrı açılan dosyalarda arşivlenmektedir. Toplam 709 yabancı sanatçı dosyası mevcut olup, bunlar klasör içinde muhafaza edilmektedir.

Arşiv'le de bağlantılı olarak Sanat Galerisi'nin faaliyetleri Sanat Odası tarafından yürütülmekte, açılan sergiler sonunda birer tablonun kütüphaneye bağışı sayesinde orijinal sanat koleksiyonu her geçen gün artmaktadır.

Sonuç olarak; Türkiye'de henüz benzeri olmayan bu Arşiv gelecek nesillere aktarılacak çok kıymetli bir hazinedir. Bilkent Üniversitesi verdiği etkin sanat eğitiminin yanı sıra çağdaş Türk plastik sanatlar konusunda hissedilen önemli bir boşluğu da bu Arşiv sayesinde doldurmuştur. 